\title{
Strategic enterprise management: de volwassenheidsfase van enterprise resource planning?
}

Citation for published version (APA):

Bollen, L. H. H., \& Vluggen, M. P. M. (2000). Strategic enterprise management: de volwassenheidsfase van enterprise resource planning? METEOR, Maastricht University School of Business and Economics. METEOR Research Memorandum No. 041 https://doi.org/10.26481/umamet.2000041

Document status and date:

Published: 01/01/2000

DOI:

10.26481/umamet.2000041

Document Version:

Publisher's PDF, also known as Version of record

Please check the document version of this publication:

- A submitted manuscript is the version of the article upon submission and before peer-review. There can be important differences between the submitted version and the official published version of record.

People interested in the research are advised to contact the author for the final version of the publication, or visit the DOI to the publisher's website.

- The final author version and the galley proof are versions of the publication after peer review.

- The final published version features the final layout of the paper including the volume, issue and page numbers.

Link to publication

\footnotetext{
General rights rights.

- You may freely distribute the URL identifying the publication in the public portal. please follow below link for the End User Agreement:

www.umlib.nl/taverne-license

Take down policy

If you believe that this document breaches copyright please contact us at:

repository@maastrichtuniversity.nl

providing details and we will investigate your claim.
}

Copyright and moral rights for the publications made accessible in the public portal are retained by the authors and/or other copyright owners and it is a condition of accessing publications that users recognise and abide by the legal requirements associated with these

- Users may download and print one copy of any publication from the public portal for the purpose of private study or research.

- You may not further distribute the material or use it for any profit-making activity or commercial gain

If the publication is distributed under the terms of Article 25fa of the Dutch Copyright Act, indicated by the "Taverne" license above, 
STRATEGIC ENTERPRISE MANAGEMENT:

De Volwassenheidsfase Van Enterprise ResourCe PlanNing?

\author{
Laury Bollen \& Mark Vluggen* \\ Maastricht Accounting and Auditing Research and Education Center (MARC) \\ Faculteit der Economische Wetenschappen en Bedrijfsadministratie \\ Universiteit Maastricht
}

MARC Working Paper MARC-WP/3/2000-03

* Corresponderend auteur: E-mail: M.Vluggen@ BERFIN.Unimaas.nl 


\section{Introductie}

In de afgelopen jaren hebben ondernemingen in sterk toenemende mate geïnvesteerd in nieuwe informatiesystemen waarbij de integratie van systemen en de ondersteuning van zowel primaire als secundaire bedrijfsprocessen centraal staan. Veel ondernemingen beschikken daardoor tegenwoordig over een Enterprise Resource Planning (ERP) pakket. Een studie van van Everdingen et al. (2000) laat zien dat de adoptie van ERP niet langer voorbehouden is aan grote ondernemingen, maar dat ook een meerderheid van de Nederlandse ondernemingen in het Midden-en Klein Bedrijf ERP software inzet in minstens één functioneel gebied.

Deze software ondersteunt niet alleen het hele scala aan bedrijfsprocessen dat zich binnen een organisatie afspeelt, maar combineert dit tevens met een integrale aanpak van de informatisering van de diverse bedrijfsprocessen. Als gevolg daarvan herbergt het transactiesysteem van deze pakketten een grote hoeveelheid bedrijfsinformatie, die vervolgens ook nog eens binnen één centrale database wordt verzameld. De beschikbaarheid van bedrijfsinformatie op operationeel niveau wordt op deze manier aanzienlijk vergroot. Daaruit ontstaat vervolgens vaak de verwachting dat de invoering van een ERP pakket ook belangrijke voordelen kan hebben voor de management informatievoorziening. Maar hoewel de verzamelde informatie in potentie veel voordelen biedt voor het verbeteren van de management-informatie, blijkt het feit dat deze informatie in een ERP systeem wordt verzameld op zich onvoldoende om een verbetering in de managementrapportage te bewerkstelligen. En daarmee vervalt feitelijk een essentieel voordeel dat aan de inrichting van een ERP pakket zou kunnen zijn verbonden.

De vraag hoe managementinformatie uit een ERP systeem te destilleren lijkt in de praktijk een zeer relevante, als we althans af mogen gaan op het aantal trainingen en congressen dat de voorbije drie jaar aan dit thema is gewijd. Uit een studie van Bothof en Götte (1998) blijkt dat de behoefte aan geïntegreerde managementinformatie inderdaad een van de belangrijkste beoogde doelstellingen van een ERP implementatie is. Daarnaast geven managers aan dat deze doelstelling ook daadwerkelijk gerealiseerd wordt bij ingebruikname van ERP software. De verbeteringen op het rapportagevlak zijn echter vooral gelegen in de management rapportages die voor de implementatie ook reeds beschikbaar waren. Deze rapportages blijken met het ERP systeem sneller en goedkoper beschikbaar te zijn. 
Davenport (2000) laat gelijksoortige resultaten zien, maar geeft tegelijkertijd aan dat de meeste ondernemingen niet in staat blijken om inhoudelijke verbeteringen van de rapportage te realiseren, noch een betere afstemming van de rapportage op de beslissingsprocessen van gebruikers. Dit leidt binnen die organisaties dan ook - terecht - tot de vraag waarom een dure en tijdrovende ERP implementatie er slechts toe heeft geleid dat men feitelijk nog steeds dezelfde informatie ter beschikking heeft als daarvoor, zij het dat het rapportageproces minder tijds-en arbeidsintensief is geworden. Deze resultaten zouden afgedaan kunnen worden door erop te wijzen dat ondernemingen pas relatief kort werken met ERP systemen. Deze redenering gaat uit van de, in principe valide, gedachte dat ondernemingen de rapportagefunctionaliteit van ERP pas kunnen gaan gebruiken als de transactieverwerking goed geregeld is. Dit artikel wijst echter in de richting van een alternatieve verklaring voor de gevonden resultaten door aandacht te besteden aan een aantal inherente rapportagebeperkingen van ERP systemen.

Indien ondernemingen daadwerkelijk voordeel willen halen uit hun ERP pakket, dienen ze het ontsluiten van de ERP databron prioriteit te geven. Voor dit doel kan gebruik worden gemaakt van analyse software, ook wel 'Business Intelligence' (BI) applicaties genoemd.

Ondernemingen die deze analyse software goed weten te gebruiken, kunnen rekenen op de volgende voordelen:

- Een kwaliteitsverbetering van informatie en een verbetering van de beschikbaarheid van informatie 'over applicaties heen';

- Nieuwe functionaliteit die het gebruikers mogelijk maakt snel en efficiënt tactische en strategische beslissingen te nemen;

- Een verminderde dataredundantie.

De opbouw van dit artikel kan geilllustreerd worden aan de hand van figuur 1. 
Concept

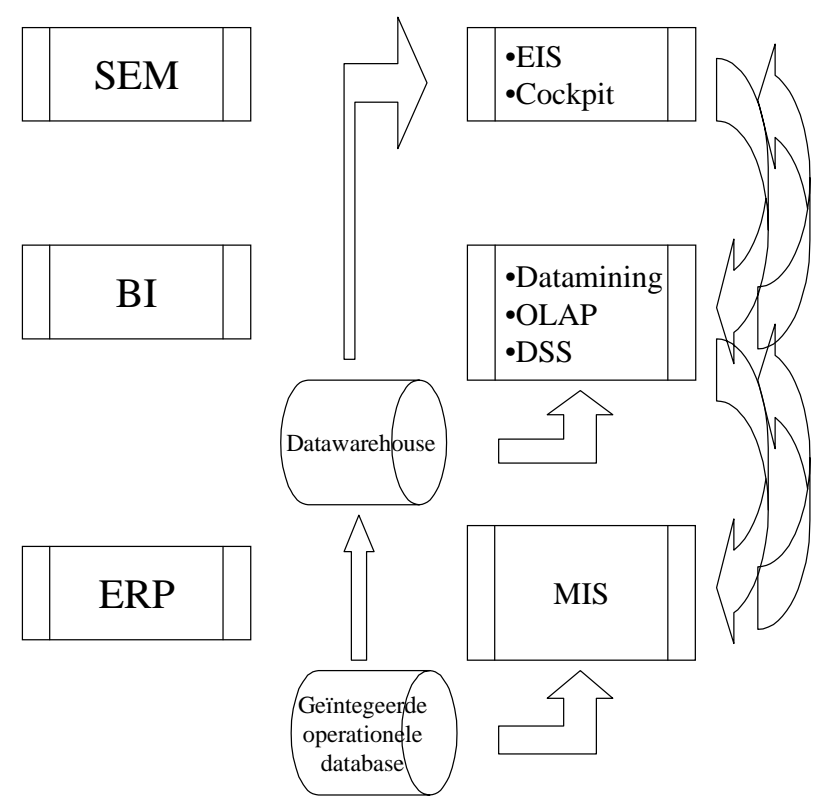

\section{Ondersteuning}

Strategisch

niveau

Tactisch niveau

Operationeel niveau

Figuur 1: ERP, BI en SEM

In deze figuur worden een drietal concepten onderscheiden: ERP, BI en Strategic Enterprise Management (SEM). In paragraaf 2 richten wij onze aandacht op ERP, en vooral op de rapportagebeperkingen van ERP pakketten. Vervolgens wordt beoordeeld in hoeverre deze rapportagebeperkingen kunnen ondervangen worden middels BI toepassingen. Daarbij wordt tevens ingegaan op de rol van data warehouses die vaak een belangrijk technisch aspect van deze toepassingen vormen en wordt een aantal specifieke toepassingen van BI systemen besproken $(\S 3)$. Tenslotte wordt aandacht besteed aan de vraag in hoeverre BI toepassingen verdere uitbouw behoeven in de richting van de informatieontsluiting op strategisch niveau binnen organisaties. Daarbij wordt de term Strategic Enterprise Management (SEM) als leidraad genomen (§4). In deze paragraaf worden tevens de interne en externe berichtgevingsimplicaties van SEM besproken.

\section{Enterprise Resource Planning: de rapportagebeperkingen}

Accounting modules mogen tot het traditioneel deel van het productaanbod van ERP leveranciers gerekend worden. Doordat ERP een eenduidige gegevensdefinitie kent, is de managementrapportage eenvoudiger geworden. Daar staat tegenover dat het hier nog altijd om standaard interne rapportages gaat. De mogelijkheid om externe databronnen te combineren met ERP 
rapportages, is nagenoeg afwezig. Overigens gelden dezelfde beperkingen op de andere traditionele delen van het ERP-productaanbod; human resource- en productiemodules. In principe kunnen de beperkingen van ERP op dit vlak als volgt samengevat worden (Bellomo, 1999):

1. ERP databases bevatten operationele gegevens (bijv. openstaande orders) terwijl er voor veel BI toepassingen veel meer behoefte is aan historische gegevens (tijdreeksen) en indelingen van gegevens die niet direct aan het operationele proces zijn gekoppeld.

2. De ERP database kan niet aangevuld worden met externe informatie. Voor beslissingen op tactisch en strategisch vlak zijn externe gegevens noodzakelijk. Hier kan bijvoorbeeld gedacht worden aan onderzoeks-, klant-, bedrijfstak- en demografische gegevens. In het algemeen geldt dat de inzet van IT in organisaties vaak beperkt is gebleven tot het verzamelen en vastleggen van interne data.

3. Rapportage 'op maat' is niet goed mogelijk zonder hulp van een programmeur omdat zij direct is gebaseerd op query-technieken die voor de gemiddelde gebruiker onvoldoende toegankelijk zijn. Daarnaast vertraagt de databasestructuur van ERP software (met bijvoorbeeld meer dan 9000 tabellen in SAP R/3) de responstijd bij een query aanzienlijk.

Als gevolg hiervan concentreren rapportages in ERP systemen zich op standaard overzichten zoals die ook al in de periode voor de ERP implementatie werden gebruikt. De genoemde rapportagebeperkingen worden ook in empirische studies onderkend. Granlund \& Malmi (2000) geven bijvoorbeeld aan dat ad hoc rapportage moeilijk is bij gebruik van ERP-pakketten. Ook de empirische studie van Booth et al. (2000), een enquête onder Australische CFO's, laat zien dat de rapportage- en beslissingondersteuningsmogelijkheden van ERP systemen minder effectief worden gevonden dan de transactieverwerkingsmogelijkheden.

De eerste twee genoemde beperkingen zijn in principe vergelijkbare problemen die beiden voortvloeien uit het feit dat ERP systemen operationele systemen zijn. Ze leggen de huidige stand van zaken vast. De derde beperking heeft enerzijds te maken met een gebrek aan flexibiliteit en functionaliteit maar ook met de beperkte beschikbaarheid van relevante data - die immers vaak niet van operationele aard zijn. 
Daarnaast geldt dat ERP databases zo ontworpen zijn dat ze op optimale wijze de transactiegegevens vastleggen, en de modulaire applicaties 'voeden' met deze gegevens. Dit maakt ze echter ongeschikt voor een multidimensionale analyse (Schroeck, 1999), waarbij gegevens worden gegroepeerd en geanalyseerd op basis van indelingen die vanuit het perspectief van de gebruiker interessant zijn (bijv. per klant, per geografisch gebied of per leeftijdscategorie). En het zijn nu juist deze analyses die voor het management van groot belang zijn. In de sfeer van controllerwerkzaamheden kan hier worden geduid op analyses die gebruik maken van historische gegevens (bijvoorbeeld bij het uitvoeren van een verschillenanalyse), combinaties van interne en externe informatie (bijvoorbeeld bedrijfstakgegevens bij benchmarking technieken) of gegevens die worden gegroepeerd op basis van geografische regio's, marktindelingen, doelgroepen et cetera. Al deze 'dimensies' zijn in een ERP omgeving niet eenvoudig in te richten gezien de transactiegerichte gegevensindeling van de ERP database. Voor een op het management afgestemde database structuur wordt daarom vaak gezocht naar een oplossing die naast de bestaande ERP database functioneert, bijvoorbeeld in de vorm van een datawarehouse. Ook komt het nog regelmatig voor dat ERP data geëxporteerd wordt naar een ander pakket (bijv. Excel), en dat met behulp van dit pakket de analyse wordt gedaan en de rapportages worden gemaakt.

Concluderend kan worden opgemerkt dat er naast het ERP systeem binnen organisaties behoefte bestaat aan aanvullende systemen die specifiek gericht zijn op het vervullen van informatiebehoeften op management-niveau. De aanwezigheid van het ERP systeem is voor de vraag naar deze nieuwe toepassingen een zeer belangrijke katalysator. Het is immers de geïntegreerde opslag van bedrijfsgegevens zoals die in een ERP systeem wordt gerealiseerd die een essentiële voorwaarde vormt voor allerlei rapportages en analyses waaraan op managementniveau behoefte bestaat. Veel ERP leveranciers breiden hun productaanbod daarom uit met tools die deze nieuwe functionaliteit kunnen bieden, zowel op het gebied van datawarehouses als op het gebied van flexibele rapportage- en analyse-tools. Desondanks bestaat er een fundamenteel onderscheid tussen de bestaande functie van een ERP systeem en de functie die deze nieuwe tools binnen de organisatie zullen gaan spelen. Hoewel deze tools formeel gezien een onderdeel kunnen uitmaken van de ERP software, is op 
conceptueel niveau een onderscheid zeer relevant. Op de specifieke kenmerken van de genoemde aanvullende systemen zullen wij in de volgende paragraaf verder ingaan.

\section{Business Intelligence systemen}

In relatie tot het probleem van flexibele rapportering en analyse van data uit hetzij een ERP systeem, hetzij een datawarehouse, valt tegenwoordig vaak de term Business Intelligence. Deze term doet ten onrechte vermoeden dat het hier om een ontwikkeling gaat die past bij reeds langer bekende toepassingen als expert systemen, kunstmatige intelligentie of neurale netwerken. BI heeft daarentegen veel meer te maken met een begrip als Decision Support Systemen (DSS) - ook wel aangeduid met de Nederlandse term Beslissingsondersteunende systemen (BOS). Al deze typen systemen hebben als doel (bedrijfs-)informatie toegankelijk te maken voor besluitvormingsprocessen op tactisch niveau. De daarvoor benodigde basisgegevens bevinden zich in de organisatie vaak op verscheidene plaatsen in diverse - vaak niet aan elkaar gekoppelde - informatiesystemen. Het in verband brengen van de term BI met het meer bekende begrip DSS laat tevens zien dat het concept van BI niet geheel nieuw is. Toch heeft het begrip een eigen plaats verworven omdat de problematiek rond het ontsluiten van bedrijfsgegevens een nieuwe impuls heeft gekregen door (a) de sterk toegenomen aandacht voor kennismanagement enerzijds en (b) de sterke opkomst van ERP systemen anderzijds.

Kennismanagement betreft het in goede banen leiden van processen van kenniscreatie, kennis vastleggen, kennis delen en kennis verspreiden, teneinde de organisatie beter te besturen en te beheersen. De beschrijving van Business Intelligence sluit hier nauw op aan. BI wordt wel omschreven als het proces van verzamelen, analyseren en verspreiden van informatie met als doel een verbetering van de bedrijfsvoering te ondersteunen. Daarbij wordt vaak aangetekend dat het er bij BI om gaat data te transformeren in informatie en deze informatie vervolgens te transformeren in kennis. BI-toepassingen moeten dus een stap verder gaan dan het genereren van informatie zoals dat gebeurt in allerlei rapportagesystemen. Het gaat er om dat deze informatie vervolgens kan worden gemanipuleerd, gecombineerd en geanalyseerd teneinde nieuwe informatie te creëren. De BI-systemen waarmee deze nieuwe informatie wordt gegenereerd vormen een belangrijk instrument waarmee de 
steeds maar toenemende snelheid en complexiteit van de besluitvormingsprocessen binnen organisaties in belangrijke mate kan worden ondersteund.

De basis voor de analyses die met BI-toepassingen worden verricht ligt vanzelfsprekend in de beschikbaarheid van operationele data. Door de opkomst van ERP systemen ontstond er binnen veel organisaties een sterke vergroting van de hoeveelheid beschikbare data. Daarnaast is deze data ook nog eens in één geïntegreerd informatiesysteem bij elkaar gebracht. Een van de knelpunten bij de inrichting van vroegere beslissingsondersteunende systemen was de grote variëteit aan applicaties (en daarmee gegevensdefinities) op operationeel niveau die in veel organisaties in gebruik waren. ERP systemen bieden door hun eenduidige gegevensdefinitie een oplossing voor dit knelpunt. Een aantal analytische applicaties zijn ontworpen voor gebruik in combinatie met een specifiek bronsysteem (bijvoorbeeld een bepaald ERP-pakket). Het proces van het onttrekken van gegevens aan de ERPdatabase, de transformatie van deze gegevens en tot slot het laden van deze gegevens in een aparte data warehouse is dan voorgedefinieerd (Eckerson, 2000). Daarmee krijgen de mogelijkheden voor beslissingsondersteunende toepassingen een enorme impuls en komen bekende toepassingen als DSS veel beter tot hun recht. Een aantal van deze toepassingen maakt direct gebruik van de (operationele) gegevens zoals die in een ERP worden verzameld en vastgelegd. Maar voor andere BI toepassingen vormt het ERP systeem geen voldoende basis en moeten aanvullende faciliteiten in de vorm van een data warehouse worden ingericht.

\subsection{BI toepassingen}

In het kader van BI-systemen zijn er vele verschillende vormen van ondersteunende systemen denkbaar. Wij zullen op deze plaats niet ingaan op de meer bekende vormen van BI-systemen zoals Decision Support Systemen (DSS). Wel willen wij kort stilstaan bij twee relatief nieuwe BItoepassingen, te weten Online Analytical Processing (OLAP) en datamining. Online Analytical Processing (OLAP) is te karakteriseren als een geavanceerde vorm van Decision Support Systemen (DSS), waarbij een analist met behulp van diverse analyse technieken grote hoeveelheden basisdata kan analyseren. De essentie van deze toepassingen is enerzijds dat eindgebruikers er volledig zelfstandig complexe analyses mee kunnen uitvoeren zonder uitgebreide ondersteuning van ICT- 
specialisten en anderzijds dat de toepassing dermate flexibel is dat er voortdurend nieuwe analyses mee kunnen worden opgebouwd ter ondersteuning van ongestructureerde en ad-hoc vraagstellingen. De kern van deze techniek is dat men in het kader van een specifieke probleemanalyse, relevante data bij elkaar brengt in een gegevenskubus waarin deze data kan worden bekeken, gegroepeerd en met elkaar in verband gebracht op basis van allerlei kenmerken die de gebruiker in het kader van die probleemstelling relevant acht. Een typische analyse die in dit verband kan worden genoemd is het zoeken naar de mogelijke oorzaak van een reeds onderkend probleem. Stel een onderneming is zich er van bewust dat haar omzet in de afgelopen twee kwartalen een dalende trend vertoont. Over de specifieke oorzaak van dit probleem tast zij echter in het duister. Toepassing van OLAP vereist dan dat allereerst de voor het probleem relevante data bij elkaar worden gebracht (bijvoorbeeld gegevens over omzet, prijzen, marketing en reclame, vergelijkbare gegevens van concurrenten) en dat al deze gegevens worden vastgelegd op basis van in deze problematiek relevante indelingen (bijvoorbeeld tijd, product, regio). Vervolgens start men een zoektocht naar de mogelijke oorzaak van het probleem door de bijeengebrachte gegevens langs verschillende assen af te zetten om te zoeken naar opvallende patronen ${ }^{1}$. Deze patronen kunnen vervolgens verder worden geanalyseerd door van een geaggregeerd niveau af te dalen naar meer gedetailleerde niveaus ${ }^{2}$ (bijv. analyses per productgroep naar individuele producten).

Datamining is een techniek waarbij men op basis van een grote hoeveelheid aan beschikbare data op zoek gaat naar patronen zonder veel inzicht in de aard van de te onderzoeken problematiek. Met behulp van geavanceerde (statistische) technieken gaat men op zoek naar geheel nieuwe relaties de in de aanwezige data kunnen worden ontdekt om vervolgens te bepalen of de gevonden relaties op enigerlei wijze kunnen worden gebruikt. Het gaat in het geval van datamining om een in hoge mate willekeurig en geautomatiseerd zoekproces dat zich op dit punt duidelijk onderscheid van een toepassing als OLAP waarbij het analyseproces veel doelmatiger is ingericht. Een belangrijke voorwaarde bij OLAP is dat er inzicht bestaat in de vraag welke data relevant is binnen het voorliggende probleem, zodat de te gebruiken gegevenskubus zinvol kan worden gevuld zodat er een redelijke zekerheid bestaat dat de OLAP-analyses worden uitgevoerd op gegevens die ook een mogelijke oorzaak van het voorliggende probleem in zich herbergen. Men zoekt als het ware een speld 
in een hooiberg, maar er is wel bekend welke hooiberg moet worden onderzocht. Bij datamining richt de analyse zich meer op het selecteren van de juiste hooiberg en men zoekt naar specifieke kenmerken, verbanden en patronen zonder veel voorkennis over de aard daarvan. Voorwaarde in deze structuur is dan ook een zo groot mogelijke hoeveelheid beschikbare data in de vorm van een datawarehouse, daar waar men bij OLAP analyses liever werkt met een beperktere set data (bijvoorbeeld in de vorm van een datamart).

Bijna vanzelfsprekend bestaan er met betrekking tot de mogelijkheden van zowel OLAP maar vooral datamining een aantal fabuleuze succesverhalen. Met name de toepassing van datamining binnen de marketingactiviteiten van ondernemingen - zoals het zoeken naar nieuwe doelgroepen of het beter afstemmen van producten en diensten op bestaande doelgroepen - biedt interessante mogelijkheden. Het behoeft echter weinig betoog dat alleen de succesverhalen de aandacht trekken terwijl situaties waar datamining niets of weinig oplevert - maar alleen veel geld kost - geen vermelding krijgen, alhoewel deze situaties zich waarschijnlijk vele malen vaker voordoen. Daarnaast geldt dat de significante relaties die door het datamining-proces worden uitgefilterd puur uit statistische verbanden bestaan die niet noodzakelijkerwijs op logische samenhang zijn gebaseerd. Het belangrijkste nadeel hiervan is dat er geen inzicht bestaat in de oorzaak van de voorkomende relatie en dus ook niet in de duurzaamheid daarvan of in factoren die de gevonden relatie kunnen vernaderen. Dat maakt het baseren van beleidsbeslissingen op basis van de resultaten van dit soort analyses een nogal hachelijke zaak.

Aan de andere kant kan het belang dat ondernemingen aan deze technieken hechten nauwelijks worden onderschat. Het verzamelen van data over klanten is voor veel ondernemingen een belangrijke activiteit geworden. Bekende spaarsystemen zoals airmiles en bonuscards, en dergelijke, hebben als belangrijkste doel het vergaren van informatie omtrent de aankopen van klanten. Ook het internet speelt een uiterst belangrijke rol in het verzamelen van informatie over aard en frequentie van bezoekers van internetsites. Middels datamining en andere technieken wordt de op die manier verzamelde informatie gebruikt om patronen in klantengedrag te ontdekken waar ondernemingen vervolgens hun producten of diensten op kunnen afstemmen. Voor de consument heeft dit als voordeel dat hij/zij producten, diensten of informatie krijgt aangeboden waarvan bij voorbaat veel beter is 
vastgesteld of ze relevant zijn voor hem/haar. Een belangrijk nadeel voor de consument is echter dat veel informatie wordt verzameld zonder dat men zich daarvan bewust is en zonder dat men er zeggenschap over heeft. Over de formele regels omtrent het op deze wijze verzamelen (en eventueel zelfs commercieel exploiteren) van informatie zal de komende jaren nog heel wat worden gedebatteerd. Maar tevens geldt dat zelfs wanneer er formele regels bestaan, de feitelijke zeggenschap over deze persoonlijke informatie nauwelijks overeenkomt met de formele zeggenschap omdat mensen zich nauwelijks bewust zijn van het feit welke informatie over hen wordt verzameld, op welke manier die informatie wordt gebruikt en hoe zij hiertegen eventueel bezwaar kunnen maken.

\section{Van BI naar SEM}

De in de voorgaande paragraaf beschreven toepassingen van Business Intelligence zijn primair gericht op het analyseren van data. Die data kan heel divers zijn (intern en extern) en de BI toepassingen zijn er op gericht uit die veelheid van data interessante nieuwe informatie te genereren. Door de flexibiliteit van de beschikbare tools zijn analyses mogelijk in het kader van een veelheid aan probleemsituaties. Daarmee zijn managers en staffunctionarissen op vooral tactisch niveau binnen de organisatie veel beter geëquipeerd dan een aantal jaren geleden.

Maar toch levert ook BI slechts voor een deel van het managementinformatieprobleem een oplossing. Wat er voor een zinvolle inzet van BI aanvullend nodig is, is sturing op een hoger niveau. Daarbij staan vragen centraal als: Welke analyses verdienen de meeste aandacht; Waar valt de meest relevante nieuwe informatie te verwachten? Een goed antwoord op deze vragen is net zo belangrijk voor een succesvolle inzet van BI, als de eerder genoemde functionaliteit en flexibiliteit van de BItools zelf.

In dit verband duikt momenteel regelmatig de term Strategic Enterprise Management (SEM) op. Deze term wordt met name door een aantal ERP leveranciers gebruikt en heeft betrekking op analytische en rapportageapplicaties op strategisch vlak. Net als bij de term BI geldt dat ook SEMtoepassingen in principe al langer bekend zijn. We denken dan met name aan toepassingen in de

richting van Executive Information Systems ${ }^{\text {B }}$ (EIS). Maar ook nu zijn er een aantal redenen voor de hernieuwde aandacht voor dit type systemen. Allereerst speelt hier wederom de brede verspreiding van 
ERP systemen een rol, waarbij de centralisatie en standaardisatie van bedrijfsinformatie een belangrijke impuls geeft voor het samenstellen van management rapportages op hoger niveau. De ontwikkeling rond datawarehouses heeft dit aspect verder versterkt, waarbij ook de betere beschikbaarheid van externe data (via internet en commerciële databases) een belangrijke impuls voor strategische toepassingen heeft gegeven. Anderzijds heeft de aansturing van organisaties op strategisch niveau het laatste decennium een enorme impuls gekregen door zaken die slechts gedeeltelijk aan ICT zijn gekoppeld. Denk hierbij aan de toenemende globalisering van de wereldeconomie, de sterk toegenomen concurrentie in vele bedrijfstakken maar ook de fundamentele veranderingen in de richting van een informatiemaatschappij. Dit heeft ertoe geleid dat in de afgelopen jaren beslissingsprocessen op strategisch niveau binnen organisaties enorm aan belang hebben gewonnen. Ook binnen het vakgebied accounting is deze belangstelling niet zonder gevolgen gebleven. Binnen management accounting is de sterke opkomst van een techniek als de Balanced Scorecard een direct uitvloeisel van de behoefte aan koppeling van strategie aan sturing en beheersing van de organisatie. Met betrekking tot de externe verslaggeving geldt dat van oudsher functionerende mechanismen van periodieke rapportage aan belangrijke belangengroepen zoals vermogenverschaffers, ter discussie staan en langzaamaan vervangen zullen worden door andere vormen van rapportage. In beide ontwikkelingen spelen ICT toepassingen op het niveau van SEM een essentiële rol door de manier waarop zij deze nieuwe structuren op een zinvolle manier ondersteunen en vorm geven.

Ter illustratie van het concept van SEM zullen in deze paragraaf beide onderwerpen nader worden beschouwd. Daarbij wordt voornamelijk aandacht geschonken aan de vraag op welke wijze ICT toepassingen deze technieken kunnen ondersteunen en wordt ingegaan op de vraag in hoeverre deze ICT toepassingen afwijken van bovengenoemde Business Intelligence systemen.

\subsection{De Balanced Scorecard}

De balanced scorecard is een instrument dat de visie en strategie van een onderneming vertaalt in doelstellingen en maatstaven, georganiseerd binnen vier perspectieven (Kaplan \& Atkinson, 1998). De ontwikkeling van dit instrument is vooral ingegeven door kritiek op het gebruik van financiële informatie als prestatiemaatstaf binnen organisaties. Financiële informatie is een zogenaamde lag 
indicator van de prestatie van de onderneming; dit betekent dat deze informatie het resultaat is van in het verleden genomen beslissingen en voltooide acties. Op het moment dat deze informatie beschikbaar wordt is het niet meer mogelijk om deze acties/beslissingen bij te stellen. Om deze tekortkoming in de rapportage op te vangen, maakt de balanced scorecard gebruik van zowel lead als lag indicators, waarbij de eerstgenoemde lead indicators prestatiemaatstaven zijn die voorspellende waarde bezitten voor toekomstige bedrijfsresultaten. Zo zullen innovaties in product of bedrijfsproces, klanttevredenheid of efficiëntie van interne bedrijfsprocessen (lead indicators) zich op termijn vertalen in hogere winstcijfers (lag indicators). De maatstaven die binnen de vier perspectieven ontwikkeld worden, kunnen dan ook als een causale keten georganiseerd worden.

De balanced scorecard wordt gezien als een van de meest succesvolle innovaties op het gebied van management accounting, althans waar het de adoptiegraad van deze techniek betreft. Veel ondernemingen hebben een balanced scorecard geïmplementeerd maar er is nog weinig onderzoek gedaan naar het succes van deze techniek. Ons inziens zal het succes voor een groot deel afhankelijk zijn van de rapportagevorm. Nog vaak wordt als rapportagevorm gebruik gemaakt van spreadsheets. Deze spreadsheet wordt voor een belangrijk deel 'gevuld' met interne gegevens uit operationele systemen (zoals ERP-systemen). Dit 'vullen' van de balanced scorecard gebeurt nog vaak in de vorm van 'overtikken' van brongegevens uit ERP-modules, met alle nadelige gevolgen van dien wat betreft de betrouwbaarheid van de gegevens en de kosten van de managementrapportage. Deze rapportagemethode lijkt een anachronisme en is dat natuurlijk feitelijk ook. Spreadsheet technologie maakt het bovendien onmogelijk om de balanced scorecard op grote schaal in te zetten, terwijl het succes van de balanced scorecard vooral afhankelijk is van de schaal waarop deze kan worden ingezet.

Inmiddels bieden enkele ERP-leveranciers alsmede enkele gespecialiseerde bedrijven dan ook geautomatiseerde balanced scorecards aan. Een goede geautomatiseerde balanced scorecard heeft o.a. de volgende kenmerken:

- Drill down methoden voor het zoeken naar oorzaken van gesignaleerde afwijkingen op hoog niveau; een geaggregeerd gegeven wordt gedesaggregeerd op steeds lagere niveaus. Een zeer gangbaar voorbeeld op berichtgevingsterrein betreft variantie-analyse, waar een geaggregeerde variantie in steeds meer onderliggende varianties wordt opgesplitst; 
- Distributiemogelijkheden via een intranet. Hierdoor kan de balanced scorecard daadwerkelijk gebruikt worden als communicatiemedium, waarbij informatie verzameld wordt op operationeel niveau, geaggregeerd wordt op ondernemingsniveau en er vervolgens feedback kan worden gegeven richting de werkvloer. Hierdoor beschikt de onderneming dus over een consistent meetinstrument voor de gehele organisatie. Bovendien wordt er op deze wijze daadwerkelijk een koppeling gelegd tussen de strategie van de onderneming en de uitvoering van de bedrijfsprocessen;

- Schaalbaarheid; de scorecard moet kortom op ieder mogelijk niveau ingezet kunnen worden; van individueel tot bedrijfsniveau. Zo kan de informatie afgestemd worden op ieders behoefte. Het automatiseringspersoneel zal een belangrijke rol spelen in het ontsluiten van de benodigde brongegevens;

- Een rapportagevorm op hoog niveau voor inzicht 'in een oogopslag'. Hierbij kan gedacht worden aan een management cockpit; een soort besturingskamer waar bedrijfsinformatie grafisch is weergegeven;

- Kwantitatieve en kwalitatieve analysemogelijkheden. Bij kwantitatieve analysetechnieken denken wij aan de eerder genoemde BI-toepassingen. Bij kwalitatieve technieken dient gedacht te worden aan tekstverwerkingstoepassingen; managers moeten de kwantitatieve rapportage kunnen aanvullen met notities waarin zij de gegevens indien noodzakelijk nader toelichten;

- Continue registratie en beoordeling wordt mogelijk. Hierbij zijn mogelijk groupware faciliteiten van belang om samen te overleggen;

ICT kan dus een belangrijke rol spelen in het gebruiken van het balanced scorecard concept. Een dergelijke gedachte ligt ook ten grondslag aan één onderzoeksvraag in de studie van Booth et al. (2000). Zij gaan na in hoeverre de ingebruikname van een ERP-systeem invloed uitoefent op de adoptie van relatief nieuwe berichtgevingstechnieken (bijv. activity-based costing, de balanced scorecard, benchmarking, gebruik van niet-financiële prestatie-indicatoren, value chain analysis). Samengevat laten de resultaten zien dat adoptie van een ERP-systeem niet als katalysator fungeert (de 
adoptie van een ERP systeem geeft geen prikkel tot adoptie van nieuwe berichtgevingstechnieken), maar wel heel nadrukkelijk een faciliterende rol heeft.

\subsection{Externe verslaggeving}

De ontwikkeling van informatiesystemen op tactisch en strategisch niveau speelt niet alleen een grote rol bij de introductie van technieken op het gebied van management accounting, ook voor de externe financiële verslaggeving kunnen er grote veranderingen plaatsvinden door de introductie van BI en SEM toepassingen.

Door de introductie van ERP-, BI- en SEM systemen verandert de structuur van dit verslaggevingsproces zowel op operationeel, tactisch als strategisch niveau in de organisatie. Op operationeel niveau leidt de inzet van geïntegreerde ERP systemen ertoe dat het vastleggen van financiële gegevens op een veel efficiëntere manier kan gebeuren. Aangezien het ERP systeem reeds alle voor de financiële verslaggeving noodzakelijke basisgegevens opslaat, is er in principe weinig behoefte aan een apart boekhoudsysteem dat dient als basis voor de financiële verslaggeving. Wel is het zo dat de manier waarop gegevens in een transactieverwerkend systeem worden vastgelegd vaak niet erg geschikt is voor periodieke rapportages. Een ERP database richt zich primair op het vastleggen van transactiegerichte data terwijl de (externe) financiële verslaggeving in belangrijke mate is gebaseerd op historische data die weliswaar is gegenereerd uit de transactiegerichte data maar op een andere manier is vastgelegd om het tijdsperspectief te behouden. Om dit verschil te overbruggen is echter geen apart accountingsysteem nodig. Veel effectiever is de inzet van een datawarehouse waarin data uit de operationele systemen wordt overgeheveld en opnieuw wordt georganiseerd zodat zij meer geschikt is voor rapportages op managementniveau. Het datawarehouse vormt dan de basis waarmee met behulp van BI-tools snel en flexibel financiële rapportages kunnen worden gegenereerd. Op dit punt lopen de theorie en de praktijk echter nogal sterk uiteen. In de meeste bestaande ERP toepassingen zijn de snelheid en kosten van financiële rapportage zeker verbeterd, maar dit is doorgaans niet bereikt via de combinatie van een ERP database, een datawarehouse en BI-tools, maar door handhaving van een separaat boekhoudsysteem waarbij het journaliseringsproces, dat wordt

gevoed vanuit transacties die in het operationele systeem worden vastgelegd, geheel is 
geautomatiseerd. In deze structuur zijn de accountingregels die bij de journalisering worden gehanteerd geheel in de programmatuur ingebakken, waardoor er een verslaggevingssysteem ontstaat dat nog statischer en sterker gestandaardiseerd is dan nu al het geval is. De flexibiliteit van de financiële rapportage neemt dan door de inzet van het ERP systeem juist verder af in plaats van dat hij toeneemt en de toepassing van BI-tools voor de financiële rapportage levert dan ook alleen voordelen in tijd en niveau van aggregatie maar niet in de flexibele toepassing van accounting regels. Zoals hierna zal worden betoogd levert deze structuur met name voor externe partijen een ernstige belemmering voor een mogelijke verbetering van het bestaande systeem van externe verslaggeving.

Met betrekking tot het tactische en strategisch niveau is het zinvol een onderscheid te maken tussen het belang van de externe verslaggeving voor het management van de onderneming en het belang van externe partijen als aandeelhouders en beleggers. Over het management willen wij hier kort zijn. Voor deze groep gebruikers zal primair het management accounting systeem als bron van informatie dienen ervan uitgaande dat ICT-toepassingen de tot op heden vaak strikte relatie tussen externe en interne verslaggeving losser zal doen worden ${ }^{4}$.

Voor externe partijen geldt als centraal probleem dat zij de inhoud van de verstrekte informatie niet kunnen afstemmen op hun informatiebehoefte. Een jaarrekening is immers samengesteld op basis van een door het management bepaalde selectie van accounting principes die niet noodzakelijk overeenkomt met de accounting technieken die gebruikers van die informatie prefereren. Een flexibel rapportage systeem houdt in deze context dan ook niet alleen in dat de tijdperiode waarover de verslaggeving plaatsvindt en het niveau van consolidatie dat voor de rapportage wordt toegepast naar behoeven kan worden aangepast, maar ook dat verslaggevingregels moeten kunnen worden gewijzigd al naar gelang de informatiebehoeften van de gebruiker. Van bestaande BI toepassingen - met name OLAP- is bekend dat het flexibel inrichten van de tijdshorizon en het niveau van aggregatie prima worden afgedekt. Maar met betrekking tot de flexibiliteit op het gebied van de te gebruiken verslaggevingregels lijkt de situatie minder gunstig. Een essentieel dilemma op dit punt is dat naarmate de verstrekte informatie meer is afgestemd op de specifieke wensen van de gebruiker of de individuele situatie van de onderneming, de vergelijkbaarheid met andere ondernemingen of de vergelijkbaarheid in de tijd meer geweld wordt aangedaan. Toch bieden 
BI- en SEM-toepassingen in combinatie met de communicatiemogelijkheden van het Internet wel degelijk nieuwe mogelijkheden om dit dilemma te overwinnen. Op dit punt wordt ons verhaal echter enigermate speculatief, aangezien vrijwel geen enkele van de mogelijke suggesties tot verbetering momenteel op de bestaande praktijk kunnen worden gebaseerd 5 . Wij willen dan ook volstaan met een korte illustratie. Ondernemingen kunnen wettelijk verplicht worden een bepaalde set aan onbewerkte basisdata op een gestandaardiseerde wijze via internet aan te bieden, analoog aan de huidige wettelijke verplichtingen ten aanzien van publicatie van de papieren jaarstukken. Een essentieel verschil is echter dat het nu gaat om onbewerkte data waarop nog geen accountingregels zijn toegepast. Vervolgens moet er worden voorzien in een centraal ontwikkelde interface waarmee gebruikers deze basisdata van publicatieplichtige ondernemingen kunnen combineren, bewerken en analyseren waarbij zij zelf bepalen welke informatie zij relevant achten en op basis van welke verslaggevingregels deze informatie moet worden opgesteld. Omdat alle publicerende ondernemingen dezelfde set aan basisdata leveren zal ondanks de individuele keuze van verslaggevingregels door gebruikers toch de vergelijkbaarheid tussen ondernemingen onaangetast blijven. In deze opzet worden flexibiliteit en vergelijkbaarheid op een unieke wijze gecombineerd. De gebruikte basisdata blijven binnen de oorspronkelijke onderneming opgeslagen, waardoor ook het garanderen van de betrouwbaarheid van deze gegevens door middel van een controle door accountants mogelijk blijft, al zal de wijze waarop die controle moet worden vormgegeven allerlei interessante nieuwe vraagstukken voor accountants opleveren.

\section{Afsluitende opmerkingen}

Door de grote ERP leveranciers (SAP, Baan, Oracle, Peoplesoft en JD Edwards) werd analysesoftware in het verleden als een niche-markt gezien. Aanvankelijk zijn dan ook vooral bedrijven als Hyperion, NCR, SAS Institute en Sybase op deze markt actief. Dat de markten voor ERP en analytische applicaties zich aanvankelijk separaat ontwikkelen is oppervlakkig gezien logisch; ERP software verschilt immers van analytische applicaties in vele opzichten (focus, gebruikers, datavolume, database-ontwerp et cetera). 
In de afgelopen jaren hebben de ERP leveranciers de functionaliteit van hun pakketten op dit vlak echter aanzienlijk verbreed, zij het dat er kritiek is op de kwaliteit van de BI-en SEMtoepassingen van de ERP leveranciers (Burwen, 2000). Toch is er een urgente noodzaak voor ERP leveranciers om zich op deze markt te gaan richten. De enorme groeicijfers die zij lieten zien in de jaren negentig, lijken verleden tijd en men werkt dan ook vooral aan uitbreiding van het productaanbod. In 1998 vermeldt Computable analysesoftware, supply chain solutions en sales force automation software als de drie nieuwe trends in ERP software. Inmiddels kunnen e-commerce toepassingen nog aan dit lijstje worden toegevoegd.

Eigenlijk observeren we bij analytische software dezelfde evolutie als bij ERP; er treedt een verschuiving op van maatwerk naar off-the-shelf software. De grote ERP leveranciers zijn actief op zowel BI als SEM vlak, zij het dat de mate waarin ze zich op deze markt profileren verschilt. Bij BI functionaliteit kan gedacht worden aan de gegevenspakhuizen die onder namen als Business Information Warehouse en Enterprise Warehouse op de markt gezet worden. Op SEM terrein kan gewezen worden op de al eerder in dit artikel aangehaalde geautomatiseerde balanced scorecard en management cockpit toepassingen.

Behalve ERP leveranciers zijn uiteraard ook kleinere, gespecialiseerde ondernemingen op deze markt actief. De keuze voor een ERP solution dan wel maatwerk is afhankelijk van de huidige stand van zaken op ERP en data warehousing terrein. Een onderneming die nog geen data warehouse in gebruik heeft, en ERP software heeft geïmplementeerd zonder grote aanpassingen, zal relatief eenvoudig een datawarehouse oplossing van de ERP leverancier kunnen implementeren. Ook van belang is de bron van de data warehouse gegevens. Indien de ERP database de belangrijkste bron van gegevens is voor het data warehouse, zal de implementatie van een ERP solution waarschijnlijk weinig problemen opleveren.

\section{Literatuur}

Bellomo, C., Unleashing The Power of ERP, DM Review Magazine, February, 1999. 
Booth, P., Matolcsy, Z., \& Wieder, B. Integrated Information Systems (ERP-Systems) and Accounting Practice - the Australian Experience, Working paper gepresenteerd op de $3^{\text {de }}$ European Conference on Accounting Information Systems, München, Duitsland, 2000.

Bothof, N.J.W., \& Götte, B.J., Enterprise Resource Planning als omwenteling- De impact van ERP op organisaties, Giarte Media Group, Amsterdam/Minneapolis, 1998.

Burwen, M.P., ERP, BI and E-Commerce: Where are the Winners?, DM Review Magazine, July, 2000.

Davenport, T.H., Mission Critical: Realizing the promise of enterprise systems, Harvard Business School Press, Boston, MA, 2000.

Eckerson, W., Understanding Packaged Analytic Applications, DM Review Magazine, March, 2000. Everdingen van, Y., Hillegersberg van, J., \& Waarts, E., ERP Adoption by European midsize companies, Communications of the ACM, nr.4, 2000, vol.43, p.27-31.

Granlund, M. \& Malmi, T., The liberations and limitations of ERP-systems for management accounting, Working paper gepresenteerd op het $23^{\mathrm{e}}$ jaarlijkse congres van de European Accounting Association, München, Duitsland, 2000.

Kaplan, R.S., \& Atkinson, A.A., Advanced Management Accounting, Prentice Hall, New Jersey, 1998.

Op Het Veld, R., Expansiedrift van ERP-pakketten, Computable, nr.29, 1998, p.33.

Schroeck, M.J., Insights From the Front Line: Maximizing the Value of ERP, DM Review Magazine, February, 1999.

\footnotetext{
${ }^{1}$ Een populaire term voor deze analyse techniek is "slicing and dicing".

${ }^{2}$ Voor deze techniek hanteert men de term "drill down".

${ }^{3}$ Een besluitvormingsondersteunend systeem dat zich speciaal richt op de ongestructureerde informatiebehoeften van het topmanagement.

${ }^{4}$ Overigens wordt er wel gesuggereerd dat de strikte relatie tussen externe en interne verslaggeving door managers in stand word gehouden als gevolg van beloningssystemen waarbij gegevens uit de externe verslaggeving een rol spelen. Een bespreking van deze problematiek valt echter buiten het kader van deze paper.

${ }^{5}$ Een belangrijke reden waarom aan de ontwikkeling van dergelijke systemen momenteel nog weinig aandacht wordt besteed is dat uit het oogpunt van een individuele onderneming er voor de inrichting van een dergelijk systeem een grote hoeveelheid gedetailleerde en moeilijk verkrijgbare gegevens uit externe bronnen (zoals concurrenten en branchegenoten) noodzakelijk is.
} 